\title{
PENGARUH PARITAS DAN MEDIA KONSELING MASA NIFAS TERHADAP KEMAMPUAN PERAWATAN MANDIRI IBU POST PARTUM DI BPM VIVI SURABAYA
}

\author{
Yunik Windarti, Uke Maharani Dewi
}

\author{
Fakultas Keperawatan dan Kebidanan \\ Universitas Nahdlatul Ulama Surabaya, Jln. Smea 57 Surabaya \\ Email : yunikwinda@unusa.ac.id
}

\begin{abstract}
In Indonesia Maternal Mortality Rate (MMR) is still high. Various attempts were made by the government to reduce AKI one of them with the implementation of adequate postnatal care. The success of postnatal care is determined by the mother's ability to care for him, especially since birth experience (parity) and the delivery of health information (media counseling) is good. The aim of research to determine the effect of parity and media postnatal counseling on self-care ability of others. postpartum Analytical research design. The population postpartum mothers day 1-10 for 30 people in BPM Vivi in April-June 2017, the sample size of 30 people were taken to the technique of "total sampling". The independent variable parity and media counseling, self-care dependent mothers. postpartum Analysis by Chi squaretest.the results showed that primiparous majority $(63.3 \%)$ are less able to perform self-care, multipara almost entirely $(78.9 \%)$, both in performing self-care with $p=0.047$. leaflet media health education with the majority ( $60.0 \%)$ less than in performing self-care, media counselor almost entirely $(86.7 \%)$ either do self-treatment with $p=0.023$. this study concluded that the higher the better parity self-care during childbirth and direct counseling method (counselor) better than the media leaflets in self-care during childbirth. Therefore for health workers in providing services to clients KIE further improve the media direct counseling.
\end{abstract}

Keywords: Parity, media counseling, self-care postpartum mothers

\begin{abstract}
Abstrak : Di Indonesia Angka Kematian Ibu (AKI) masih tinggi. Berbagai upaya dilakukan oleh pemerintah untuk menurunkan AKI salah satunya dengan penyelenggaraan perawatan nifas yang adekuat. Keberhasilan perawatan nifas ditentukan oleh kemampuan ibu dalam merawat dirinya terutama karena pengalaman melahirkan (paritas) dan penyampaian informasi kesehatan (media konseling) yang baik. Tujuan penelitian untuk mengetahui pengaruh paritas dan media konseling masa nifas terhadap kemampuan perawatan mandiri ibu post partum. Desain penelitian analitik. Populasinya ibu nifas hari ke-1-10 sebesar 30 orang di BPM Vivi pada bulan April - Juni 2017, besar sampel 30 orang diambil dengan teknik "total sampling". Variabel independen paritas dan media konseling, dependennya perawatan mandiri ibu post partum. Analisis dengan Chi Square test. Hasil penelitian menunjukkan bahwa primipara sebagian besar $(63,3 \%)$ kurang mampu melakukan perawatan mandiri, multipara hampir seluruhnya $(78,9 \%)$ baik dalam melakukan perawatan mandiri dengan $\mathrm{p}=0,047$. Pendidikan kesehatan dengan media leaflet sebagian besar $(60,0 \%)$ kurang dalam melakukan perawatan mandiri, media konselor hampir seluruhnya (86,7\%) baik melakukan perawatan mandiri dengan $p=0,023$. Penelitian ini menyimpulkan bahwa semakin tinggi paritas semakin baik perawatan mandiri masa nifas dan metode konseling langsung (konselor) lebih baik daripada media leaflet dalam perawatan mandiri masa nifas. Oleh karena itu bagi tenaga kesehatan dalam memberikan pelayanan KIE pada klien lebih meningkatkan media konseling langsung.

Kata kunci: Paritas, media konseling, perawatan mandiri ibu nifas
\end{abstract}




\section{PENDAHULUAN}

Strategi untuk meningkatkan derajat kesehatan masyarakat mencakup pelayanan kesehatan bagi seluruh kelompok usia mengikuti siklus hidup sejak dari bayi, anak, remaja, kelompok usia produktif, maternal, dan lansia.

Ibu merupakan seorang yang mempunyai peran penting dalam kelangsungan hidup keluarga. Siklus menjadi seorang ibu, perempuan harus melewati kehamilan, persalinan, dan masa nifas. Hal tersebut sangat mempengaruhi fisik, psikologis, maupun sosial ibu. Saat masa nifas, seorang ibu bukan hanya mengurus dirinya sendiri, tetapi juga mengurus bayinya. Pengelolaan perawatan nifas yang adekuat perlu dilakukan untuk menurunkan AKI, disamping upaya pelayanan kesehatan pada masa kehamilan dan persalinan yang telah dilakukan sebelumnya.

Faktor yang mempengaruhi kemandirian ibu dalam melakukan perawatan diri dan bayi adalah pengalaman di masa lalu karena seseorang telah mengalami proses belajar dalam hal cara merawat diri. Apabila ibu sudah mengenal manfaat perawatan diri atau tehnik yang akan dilakukan, maka ibu akan lebih mudah dalam melakukan perawatan diri pasca bersalin. Bidan sebagai salah satu tenaga kesehatan yang berperan penting dalam penyampaian informasi kesehatan, berkewajiban untuk memberikan penyuluhan kepada ibu dengan metode yang tepat.

Perawatan yang dibutuhkan ibu selama masa nifas yaitu memantau dan mempertahankan kesehatannya dengan memberikan informasi kesehatan dan keterampilan yang tepat. Kebutuhan perawatan masa nifas antara lain pemenuhan kebutuhan nutrisi dan cairan, ambulasi, eliminasi, kebersihan diri, istirahat, seksual, senam nifas, perawatan payudara, teknik menyusui yang benar, perawatan luka dan pengawasan involusi uteri (Yanti, 2011).

\section{METODE}

Desain penelitian adalah analitik. Populasi dan sampel penelitian adalah post partum hari $1-10$. Sampel menggunakan total sampling sebanyak 30 responden. Variabel independen adalah paritas dan media konseling masa nifas sedangkan variabel dependen adalah perawatan mandiri ibu post partum.

Data dianalisis dengan menggunakan Chi Square Test. Pengaruh variabel independen ke variabel dependen ditunjukkan oleh nilai $p$.

Penelitian dilakukan di BPM Vivi Surabaya pada bulan April sampai Juni 2017. BPM ini memberikan layanan pemeriksaan kehamilan, persalinan, pemeriksaan ibu nifas, pemeriksaan bayi dan balita, pelayanan KB, dan Kesehatan reproduksi remaja.

\section{HASIL DAN PEMBAHASAN}

\section{Hasil Penelitian}

Tabel 1 Distribusi frekuensi responden berdasarkan paritas

\begin{tabular}{|c|c|c|}
\hline W: $\quad P O M N$ & Bandentín & 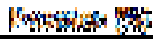 \\
\hline h fropas. & di & $34_{5} 5$ \\
\hline 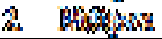 & is & $\pi$ \\
\hline Inomes & " & 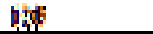 \\
\hline
\end{tabular}

Tabel 1 menunjukkan bahwa dari 30 responden sebagian besar $(63,3 \%)$ multipara.

Tabel 2 Distribusi frekuensi responden berdasarkan media konseling

\begin{tabular}{|c|c|c|}
\hline 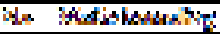 & endwexast & 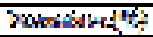 \\
\hline T. TAC'LA. & 14 & W \\
\hline i. Ruvint:e & is & $\%$ \\
\hline प्रक्षीस्र & $+\pi$ & WE \\
\hline
\end{tabular}

Tabel 2 menunjukkan bahwa dari 30 responden masing-masing setengahnya (50 \%) menggunakan media leaflet dan dengan konselor.

Tabel 3 Distribusi frekuensi responden berdasarkan perawatan mandiri

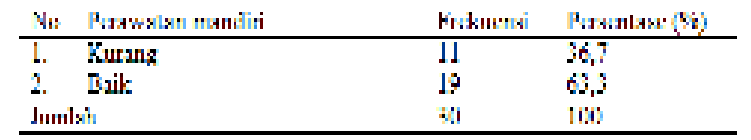


Tabel 3 menunjukkan bahwa dari 30 responden sebagian besar (63,3\%) melakukan perawatan mandiri dengan baik.

Tabel 4 Tabulasi silang paritas dengan perawatan mandiri

\begin{tabular}{|c|c|c|c|}
\hline \multirow[b]{2}{*}{ Paritas } & \multicolumn{2}{|c|}{ Perawatan Msndii } & \multirow{2}{*}{$\begin{array}{l}\text { Jumlah } \\
\text { n }(\%)\end{array}$} \\
\hline & $\begin{array}{l}\text { Kurang } \\
\text { a }(\%)\end{array}$ & $\begin{array}{l}\text { Baik } \\
\text { I }(\%)\end{array}$ & \\
\hline Primipara & $7(633)$ & $4(36,4)$ & $11(100)$ \\
\hline Maltipan & $4(21.1)$ & $15(78,9)$ & $19(100)$ \\
\hline Junlah & $11(36,7)$ & $19(63.3)$ & $30(100)$ \\
\hline $\mathrm{P}=0,047$ & \multicolumn{3}{|c|}{$\mathrm{OR}=6,563(95 \% \mathrm{Cl}: 1,259-34,203)$} \\
\hline
\end{tabular}

Tabel 4 menunjukkan dari 11 responden primipara sebagian besar $(63,3 \%)$ kurang dalam melakukan perawatan mandiri, 19 responden multipara hampir seluruhnya $(78,9 \%)$ baik dalam melakukan perawatan mandiri.

Tabel 5 Tabulasi silang media konseling dengan perawatan mandiri

\begin{tabular}{|c|c|c|c|}
\hline \multirow[b]{2}{*}{ Media Konseling } & \multicolumn{2}{|c|}{ Perawatan Mandiri } & \multirow{2}{*}{$\begin{array}{l}\text { Jumlah } \\
\text { a }(\%)\end{array}$} \\
\hline & $\begin{array}{l}\text { Kurang } \\
\text { D }(\%)\end{array}$ & $\begin{array}{l}\text { Baik } \\
\text { n (\%) }\end{array}$ & \\
\hline Leaflet & $9(60,0)$ & $6(40,0)$ & $15(100)$ \\
\hline Konsclor & $2(13,3)$ & $13(86,7)$ & $15(100)$ \\
\hline Jumlah & $11(36.7)$ & $19(63,3)$ & $30(100)$ \\
\hline$P=0,023$ & $=9.750095$ & $1,592-59$ & \\
\hline
\end{tabular}

Tabel 5 menunjukkan dari 15 responden dengan media leaflet sebagian besar $(60,0 \%)$ kurang dalam melakukan perawatan mandiri, 15 responden dengan media konselor hampir seluruhnya $(86,7 \%)$ baik dalam melakukan perawatan mandiri.

Tabel 6 Uji regresi logistik

\begin{tabular}{|c|c|c|c|c|c|}
\hline \multirow[b]{2}{*}{ Variabel } & \multirow[b]{2}{*}{ Wald } & \multirow[b]{2}{*}{ OR } & \multicolumn{2}{|c|}{ Interval Keyakinan $95 \%$} & \multirow[b]{2}{*}{ Nilai P } \\
\hline & & & $\begin{array}{l}\text { Batas } \\
\text { bawah }\end{array}$ & Batas atas & \\
\hline Konstanta & 5,803 & 0.001 & & & 0,016 \\
\hline Paritas & 4,600 & 12,602 & 1,244 & 127,666 & 0,032 \\
\hline Media kouseling & 5,583 & 17,610 & 1,631 & 190,161 & 0,018 \\
\hline $\begin{array}{l}\text { NObservasi } \\
-2 \text { log likclihood } \\
\text { Nagelkerke R } \\
\text { square }\end{array}$ & \multicolumn{5}{|l|}{$\begin{array}{l}30 \\
25,648 \\
0,504\end{array}$} \\
\hline
\end{tabular}

Tabel 6 menunjukkan secara parsial terdapat pengaruh yang signifikan paritas $(\mathrm{p}=0,032)$ dan media konseling $(\mathrm{p}=0,018)$ terhadap perawatan mandiri.
Hasil analisis didapatkan nilai OR dari paritas $12,602(95 \% \mathrm{CI}: 1,244-127,666)$ dan OR media konseling 17,610 $(95 \% \mathrm{CI}$ : 1,631- 190,161). Responden dengan paritas tinggi (multipara) berpeluang melakukan perawatan mandiri lebih baik sebesar 12 kali dibandingkan responden dengan paritas rendah (primipara). Responden yang mendapat konseling langsung (konselor) berpeluang dapat melakukan perawatan mandiri lebih baik sebesar 17 kali dibandingkan responden yang mendapat konseling dengan media leafleat.

\section{Pembahasan \\ Paritas terhadap perawatan mandiri ibu post partum}

Hasil analisis menunjukkan bahwa terdapat pengaruh yang signifikan antara paritas dengan perawatan mandiri. Perempuan primipara sebagian besar kurang mampu melakukan perawatan mandiri, sedangkan multiipara hampir seluruhnya memiliki kemampuan yang baik dalam melakukan perawatan mandiri. Hal itu menunjukkan bahwa pengalaman melahirkan merupakan faktor yang mendukung kemampuan seorang ibu post partum dalam melakukan perawatan masa nifas. Primipara belum berpengalaman merawat diri maupun bayinya, sehingga masih cenderung belajar dan berusaha lebih keras menyesuaikan kondisinya daripada multipara karena pada multipara telah memiliki pengalaman dan cenderung berusaha lebih baik dari pengalamannya dulu. Hal itu sejalan dengan pendapat Prawiroharjo (2009) yang menjelaskan bahwa faktor yang mempengaruhi paritas adalah pendidikan, pekerjaan, ekonomi, latarbelakang budaya, dan pengetahuan.

Perawatan mandiri yang dilakukan ibu nifas meliputi kebersihan diri, istirahat, nutrisi, pemberian ASI, senam nifas. Hasil penelitian menunjukkan banyak ibu nifas yang masih takut membersihkan genetalia terutama pada 
luka jahitan perineum dan pelaksanaan senam nifas yang masih belum teratur karena berbagai hambatan diantaranya kurangnya komitmen. Pemenuhan kebutuhan nutrisi sudah baik sesuai yang diharapkan. Dukungan keluarga juga sangat membantu ibu dalam menfasilitasi proses ini.

\section{Media konseling terhadap perawatan mandiri ibu post partum}

Hasil analisis menunjukkan bahwa ada pengaruh media konseling terhadap perawatan mandiri post partum. Media leaflet yang digunakan dalam pendidikan kesehatan sebagian besar ibu nifas kurang dalam melakukan perawatan mandiri, dengan media konselor hampir seluruhnya ibu nifas sudah baik dalam melakukan perawatan mandiri. Hal ini menunjukkan bahwa dengan konseling langsung (adanya konselor) lebih bermakna dalam hal penyampaian informasi daripada menggunakan media leaflet.

Media apapun pada dasarnya baik karena mempunyai kelebihan dan kekurangan masing - masing. Media konseling langsung akan lebih jelas dalam memahami setiap hal yang harus dilakukan selama merawat diri pada masa nifas. Jika ada materi yang kurang jelas dapat menanyakan secara langsung. Hal ini sesuai dengan Cangara (2012) bahwa dalam komunikasi antar manusia media yang paling dominan adalah pancaindra manusia seperti mata dan telinga. Pesan pesan yang diterima pancaindra selanjutnya diproses dalam pikiran manusia untuk mengontrol dan menentukan sikapnya terhadap sesuatu sebelum dinyatakan dalam tindakan.

Konseling memungkinkan individu mengambil keputusan berkaitan dengan hal penting bagi dirinya. Keputusan tersebut merupakan pilihan dari klien sendiri, tidak ditentukan oleh konselor. Klien belajar mengestimasi konsekuensikonsekuensi yang mungkin terjadi dalam pengorbanan pribadi, waktu, tenaga, uang, risiko, dan lain- lain (Pieter, 2012). Keberhasilan dalam penyampaian informasi sehingga ibu nifas sebagian besar mampu melalukan perawatan masa nifas diperkuat dengan pendapat Lubis (2011) yang menyatakan bahwa keberhasilan konseling sangat ditentukan oleh hubungan baik antara konselor dan klien. Konselor yang baik dalam menjalin rapport dengan klien akan lebih mampu mengantarkan konseling kepada kesuksesan. Kemampuan bidan dalam memberikan konseling pada ibu nifas sudah terbukti lebih baik.

Hasil analisis multivariat secara simultan (kecocokan) didapatkan nilai signifikan antara variabel independen (paritas dan media konseling) dengan variabel dependen (perawatan mandiri) berarti variabel faktor risiko memenuhi syarat uji simultan (kecocokan model). Variabel paritas dan media konseling secara parsial berpengaruh terhadap kemampuan perawatan mandiri ibu post partum.

\section{SIMPULAN}

\section{Simpulan}

Terdapat pengaruh signifikan antara paritas, media konseling terhadap kemampuan perawatan mandiri ibu post partum.

\section{Saran}

Pentingnya kemampuan komunikasi atau KIE terutama pada calon mahasiwa kebidanan dan keperawatan sehingga institusi pendidikan harus melatih kemampuan tersebut agar kompeten di bidangnya. Bagi tenaga kebidanan dan keperawatan yang bekerja di pelayanan dapat menggunakan multi metode dan multi media sesuai dengan kebutuhan topik pendidikan kesehatan bagi ibu post partum.

\section{DAFTAR PUSTAKA}

Cangara, Hafied. 2012. Ilmu Komunikasi. Jakarta: Rajawali Press 
Depkes. 2016. Laporan kinerja kementerian kesehatan tahun 2015. Jakarta : Http: lakipkemenkes-2015.pdf. Diakses 28 Februari 2017

Lubis, Namora. 2011. Memahami Dasar - Dasar Konseling Dalam Teori dan Praktik. Jakarta: Prenada Media Group

Murti, B. 2011. Validitas dan reliabilitas pengukuran. Fakultas Kedokteran Universitas Sebelas Maret Surakarta

Nursalam. 2011. Metodologi Penelitian Ilmu Keperawatan. Jakarta: Salemba Medika

Prawirohardjo, S. 2009. Ilmu kebidanan. Jakarta: YBP-SP

Pieter, H. 2012. Pengantar komunikasi dan konseling dalam praktik kebidanan. Jakarta: Kencana prenada media group

Yanti, Damai dan Sundawati, D. 2011. Asuhan kebidanan masa nifas belajar menjadi bidan profesional. Bandung: Refika aditama 